\author{
X.P. Uimanova*(D), M.G. Kakishev $(i)$ \\ West Kazakhstan University named after Makhambet Utemisov, Kazakhstan, Uralsk \\ *e-mail: xeniya.destination@yandex.ru
}

\title{
LEXICO-STYLISTIC PECULIARITIES OF ENGLISH LITERARY TEXT
}

This article examines the lexical and stylistic features of literary texts using the example of Nelle Harper Lee's work "Go, Set a Watchman", which was published in 2015. Nelle Harper Lee is one of the most remarkable American writers of the XX century, famous for her book "To Kill a Mockingbird" which is thoroughly studied in schools and higher educational institutions in America. Since the book "Go, Set a Watchman" was published recently, there is still no sufficiently complete and detailed analysis of this work by the American writer, which confirms the relevance of our article. Our goal is to establish the characteristic features inherent in the text of a given author by analyzing lexical and stylistic aspects. We focused specifically on a literary work since the style and expressive means of the writer's language are clearly traced in such works. Through consideration of the lexical and stylistic features common to literary texts, we found many examples in the book "Go, Set a Watchman", among which are stylistic means, such as epithets, metaphors, as well as slang, and colloquial vocabulary prevails in the author's style. The results of this work can be used in teaching students of philology.

Key words: linguostylistics, stylistic features, lexical features, literary text, Harper Lee.

\author{
К.П. Уйманова*, М.Г. Какишев \\ Махамбет Өтемісов атындағы Батыс Қазақстан университеті, Қазақстан, Орал қ. \\ *e-mail: xeniya.destination@yandex.ru
}

Ағымшын тіліндегі көркем мәтіндердің лексикалық-стимистикамық ерекшеліктері

Бұл мақалада 2015 жылы жарық көрген Нем^ Харпер Аидің “Иди, поставь сторожа" шығармасының мысалы арқылы әдеби мәтіндердің лексикалық және стильдік ерекшеліктері қарастырылады. Нем Харпер ^и - XX ғасырдағы ең көрнекті америкалық жазушылардың бірі, Америкадағы мектептер мен жоғары оқу орындарында оқытылатын «Убить пересмешника» кітабымен танымал. Біздің мақаламыздың өзектілігі - «Иди, поставь сторожа» кітабы жақында ғана жарық көргендіктен, америкалық жазушының бұл жұмысына әлі толық және егжейтегжейлі талдау жоқ болғаны. Біздің мақсатымыз - лексикалық және стилистикалық аспектілерді талдау арқылы осы автордың мәтініне тән белгілерді анықтау. Біз көркем шығармаға ерекше назар аудардық, өйткені дәл осындай шығармаларда жазушының тілінің стилі мен экспрессивті құралдары айқын көрінеді. Көркем мәтіндерге ортақ мексикалық және стилистикалық ерекшеліктерді қарастыру арқылы біз «ИАи, поставь сторожа» кітабынан көптеген мысалдарды таптық, олардың арасында эпитеттер, метафоралар, сонымен қатар сленг сияқты стилистикалық, құралдар бар, ал авторлық стильде ауызекі лексика басым екені анықталды. Бұл жұмыстың нәтижелерін филолог студенттерді оқытуда пайдалануға болады.

Түйін сөздер: ^ингвостилистика, стилистикалық ерекшеліктер, лексикалық ерекшеліктер, көркем мәтін, Харпер Аи.

\section{К.П. Уйманова*, М.Г. Какишев}

Западно-Казахстанский университет имени Махамбета Утемисова, Казахстан, г. Уральск

*e-mail: xeniya.destination@yandex.ru

\section{Аексико-стилистические особенности художественных текстов на английском языке}

Аанная статья посвящена рассмотрению лексико-стилистических особенностей художественных текстов на примере произведения Нем Харпер $\bigwedge и$ «ИАи, поставь сторожа», которое было опубликовано в 2015 г. Нелм Харпер Аи является одной из самых выдающихся американских писательниц XX века, прославившейся своей книгой "Убить пересмешника», которая досконально изучается в школах и высших учебных заведениях в Америке. Так как книга «ИАи, поставь сторожа» была опубликована недавно, еще нет достаточно полного и детального 
анализа данной работы американской писательницы, что подтверждает актуальность нашей статьи. Нашей целью является установление характерных черт, присущих тексту Аанного автора, путем анализа лексических и стилистических аспектов. Мы слелали акцент именно на художественном произведении, так как именно в таких произведениях ярко прослеживаются стиль и выразительные среАства языка писателя. ПосреАством рассмотрения общих Аля художественных текстов ^ексико-стилистических особенностей мы обнаружили много примеров в книге "ИАи, поставь сторожа», среди которых стилистические среАства, такие как эпитеты, метафоры, а также сленг, а в авторском стиле преобладает разговорная мексика. Результаты Аанной работы могут быть использованы при обучении студентов филологов.

Кмючевые слова: ^ингвостилистика, стилистические особенности, ^ексические особенности, художественный текст, Харпер Аи.

\section{Introduction}

The analysis of aspects of English speech is of particular interest in the study of linguistics. One of the best sources for conducting research on the functioning of a living language, in our opinion, are authentic samples of works of fiction because such works have integrity and inner completeness, comprehensive ideological and aesthetic meaning. The works of literature reflect the reproduction of actual reality and show how the author perceives life. (Esin, 2000: 4)

One ought to keep in mind that people live in the world of culture. Consequently, the essential characteristics of the text are largely determined by the culture, especially since the texts themselves are part of it. At the same time, literature and works of literary texts help to understand not only the culture, but also the lifestyle and events of different eras, thereby allowing readers to enrich their horizons and have new experience and emotions. (McGee, 2002: 2)

We consider in this article an example of a literary text taking into account the analysis of lexis and stylistics - which is one of the sections of linguistics that studies the styles of a literary language and the language means that create their features since in recent years it has been generally recognized that there can be no one-sided survey of the text.

During the linguistic text analysis, scientists determine the main semantic shades of words, expressions, and other linguistic phenomena, while the linguistic-stylistic analysis has the text as its object of study and considers how the images are transformed into literary speech.

Touching upon such a subject as linguo-stylistic analysis, the concept of the text itself should be defined more precisely. The text is "a verbal speech product in which all language units are realized" (Babenko, 2005: 12). In addition, it is a multi-level system, where all the components are in unbreakable agreement, which helps to accurately convey the author's point of view. (Simpson, 2004: 5) The author's picture of the world is reflected in a literary work not always explicitly and openly, sometimes it is disguised as the speech of the main characters of this work, who also express their point of view not directly with the help of words, but through emotions, behavior and attitude towards people or situations occurring around. In this aspect, a literary text can have a strong, especially aesthetic impact on the reader.

The object of linguistic-stylistic analysis is just a literary text, but not the fiction work itself. Therefore, "the text is one of the parts of the work, an extremely significant part, without which a work of fiction is impossible to exist." (Lotman, 1972: 24)

The second aspect that should be mentioned is the concept of style, which is inextricably linked with the text since it directly expresses on paper what was said and in what manner or style. The authors offer many definitions of this notion, we consider only one presented in Halperin's book about the style of the English language. In this work, style is equated with individual creativity, since the means of language used to form and express a creative idea are selected by each person, in our case by the author, individually. In general, style is "a linguistic expression of thought with an emphasis on the aesthetic-artistic or ideological concept of the author." (Halperin, 1981: 14)

Having considered the definitions of text and style, this is preeminently the time to discuss the expressive means classifications since they are the means by which the author creates his/her work. Such tools are an integral part of linguistic and stylistic analysis, which is carried out at several levels: phonological, morphological, lexical and syntactic. In this article we are covering the lexical level. Lexical means are those means which are figurative and mainly involve transferring the properties of the first object to the second one. Below we will demonstrate some of the examples and main definitions of them: 
1. Hyperbole is a means that contains a deliberately blatant overestimation of the properties of an object or phenomenon.

2. Litotes are a tool that contains an intentional underestimation of the characteristics of an object or phenomenon.

3. Irony is a means which quite commonly involves the use of phrases in a slightly negative context, which is directly opposite to their primary meaning.

4. Metaphor is a tool that "denotes transference of meaning based on resemblance or on the associated likeness between two objects". (Sachkova, 2012: 24)

5. Oxymoron is "a combination of words with a reverse interpretation". (Zherebilo, 2010: 234)

6. Personification is a means that endows an inanimate object with the qualities and characteristics of a living object or person.

7. Simile is a means of identification of one object with another one by a juxtaposed feature.

8. "An epithet is a stylistic device, based on the interplay of emotive and logical meaning in an attributive word, phrase or sentence". (Sachkova, 2012: 86)

9. Wordplay is a stylistic means for expressing humor, through play on words, where two unrelated meanings are combined. (Simpson, 2004: 45)

10. Synonyms are same word class words, expressing the same concept, meanwhile differing in shades of meaning.

11. Antonyms - different words related to the same word class, but opposite in meaning.

The commonality of the means of expression in a literary work helps to reveal not only the author's idea, but also outlines both the superficial and the deep aspects of the work, and serves as a support in identifying the features of the functioning of the living English language.

Having regard to the above, for instance, the book of the twentieth century by the author Harper Lee "Go, Set a Watchman", which was published in 2015, was considered. The book was completed before the publication of her most famous novel «To Kill a Mockingbird" (winner of the Pulitzer Prize in 1961), but was not published. (Haggerty, 2010: 6) This work of Harper Lee is insufficiently researched, and extensive scientific works on this issue in stylistics, linguistics and literary studies are not found. This article systematizes the basic principles of lexico-stylistic analysis of the text, presents the main expressive means. The novelty of our work lies in the fact that Harper Lee's work "Go, Set a Watchman" has not previously been subjected to a multifaceted stylistic analy- sis; there are also no methodological publications of this novel. This work has significant practical meaning because the conclusions of this article can be incorporated during the lessons of literary studies or foreign languages focusing on stylistic aspects of the language, translation practice or analytical reading.

\section{Material and Methods}

We acknowledge the comparative-stylistic method as the main method of research in our work since this method allowed us to study the individual style of the author with her literary techniques by identifying similar and different language expressions for the same contents.

Moreover, to prepare this scientific article, we resorted to analysis and reviewed the works of many national and foreign authors who have been dealing with the issues of stylistics and linguistics. Major foreign authors include Ronald Carter, Paul Simpson, Andrew Haggerty and Michael Toolan. The main material for the work was the book of Harper Lee "Go, Set a Watchman", where, using a continuous sample, we illustrated examples of the author's use of certain linguistic and stylistic means.

\section{Literature review}

Having examined many works of researchers, we would start with defining the term "text" proposed by the authors, especially paying attention to the literary text and its role in linguistic analysis.

"The text is a work of speech creative process, objectified in the form of a written document, literary processed in accordance with the type of the document, consisting of the name (heading) and a number of special units (over-phrasal unities), combined with different types of lexical, grammatical, logical, stylistic links with a specific purpose and pragmatic reasons". (Halperin, 1981: 18)

Texts, according to L.V. Shcherba - are "the totality of everything spoken and understood in a certain specific situation in a particular era of the life of a given social group". (Shcherba, 1974: 26)

Linguo-stylistic analysis of the text includes a comprehensive study of literary texts. The first scientists to conduct this analysis of a literary work were V.V. Vinogradov and L.V. Shcherba. The former proposed to use the projection method in literature works, where the language stands at the junction of the literary and linguistic contexts. For the latter, it was important to determine the semantic shades of linguistic expressions. 
"In the image of the author, in its speech structure, all the qualities and features of the style of a literary work are combined: the distribution of light and shadow using expressive speech means, transitions from one style of presentation to another, iridescences and combinations of verbal colors, the criteria for assessments expressed through the selection and change of words and phrases, the peculiarity of syntactic movement. This opens up the deepest layer in the stylistic study of fiction". (Vinogradov, 1971: 181)

One of the important aspects of linguistics is that one should consider a literary text in connection with everyday discourse since stylistics considers what the author does with and through language. (Simpson, 2004: 98)

The literature presents a language that embodies the artistic spirit of the writer. Each era of literature has its distinctive writing style. (Simpson, 2004: 98)

In some sources, written by authors such as Ronald Carter, linguistic stylistics is called a pure form of stylistics, for the reason that there is also an analysis of style and language, which facilitates the progression of linguistic theory. Currently, many studies of linguistic stylistics examine literary texts in more detail involving discursive and narrative analyses.

Among the scholars who studied linguistic stylistics were also A. Banfield and D. Burton, who emphasized its pros and cons. Among the positive aspects, there is a suitable scientific manner by which the use of this model becomes possible. (Carter, 1989: 4)

Regarding the distinctive feature of the style of literary texts, R. Carter writes that it helps to better understand, evaluate and interpret literary texts, where the author is at the center. This analysis takes place on numerous levels since the style itself stems from the simultaneous interaction of many levels of language organization. (Carter, 1989: 6)

When linguists consider differences in style, such as the difference between literary style and scientific style, they normally focus on the structures and distribution of language elements. In the literary style, there may be numerous elements in the texts, such as epithets, metaphors, allegory, similes, or only some of them. All of them are functionally various but implemented for similar reasons, such as making the text more colorful or vibrant as well as more engaging and appealing for the readers. Also, these texts are characterized by the use of elements of other styles which is most commonly noticed in the direct speech of the heroes who normally would use a conversational style. Those authors who fully master the literary word can easily involve their audience in the plot.
Stylistics analyzes expressive means, their essence, functions, classifications and various interpretations.

"A stylistic device is a purposeful use of linguistic phenomena, including expressive means. Expressive means have a greater degree of predictability compared to stylistic techniques. They are used to enhance the expressiveness of the utterance; they are not related to the figurative meanings of the word". (Gegel, 1968: 145)

\section{Results and Discussion}

The major distinction between the literary style and others is the appropriate use of stylistic devices by the author in the text since they are the fundamental element of this style. For example, in their works, the writers rely on metaphors to demonstrate the inner emotions of the main characters. With the help of this stylistic technique, the writer creates a figurative artistic representation of the people, phenomena, and objects that he/she describes, and the reader realizes what similarities the connotation of the word is based on.

However, one should not confuse metaphors with lexical phrases since they usually use words by association, unlike metaphors, which are the result of creative work. (Toolan, 2013: 179)

From the metaphors in the book "Go, Set a Watchman", we can demonstrate the following: Fall was hot-supper time; an ordinary turnip-sized bigot; pummeling activity; the sun had not yet blistered. Impersonation is another type of metaphor when the transfer of a feature is carried out from a living object to an inanimate one. When personified, the described object is externally likened to a person, which makes the content of the literary text more understandable and colorful. To demonstrate this lexical technique, we found the following examples in the text - "The thermometer on the back porch stood at ninety-two; the carhouse shimmered faintly in the distance and the giant twin chinaberry trees were deadly still." (Lee, 2015: 43)

"Two big tears had run from beneath his glasses down the sides of his cheeks". (Lee, 2015: 49)

"The courthouse clock creaked, strained, said, "Phlugh!" and struck the hour." (Lee, 2015: 73)

In her work, Harper Lee uses a fairly large number of similes, many of which are related to comparisons of phenomena and people with animals: honked like a giant goose; he would rush like a bat out of hell; one son looked and behaved like a horse; he was like a small panther; Underwood inhaled like a whale; work like a dog. The rest only point out the similarity of the phenomena or the character 
through other comparisons - "his crew cut bristled like an angry brush" (Lee, 2015: 11); "behaving like a snake healer" (Lee, 2015: 39); "whirlwind of impatience" (Lee, 2015: 141).

Also, in English, there are still such opposite figures as hyperbole and litotes. These devices mean exaggeration and understatement respectively, and they contribute to making the language brighter and clearer. (Sachkova, 2012: 41)

The use of hyperbole in this novel is characterized to a greater extent by the fact that Scout and her friends, who are the main characters in this text, are children and that is why tend to exaggerate a lot. The author uses them to intensify the artistic impression. For example, "you'll be boiled alive in that sun" (Lee, 2015: 41); "Calpurnia nearly took the skin off her with the rough towel" (Lee, 2015: 48); "he always runs up stairs a mile a minute" (Lee, 2015: 55); "when it's written down he always believes every word of it" (Lee, 2015: 141).

In the novel, epithets are widely presented, which distinguish its main qualities, properties and signs in objects or phenomena. (Sachkova, 2012: 33) Basically, epithets are expressed by adjectives. Lee includes the epithets in her book in order to intensify the features of certain things which should be noticed by the reader. The examples from the book include the following: reckless, pummeling activity; alarming inefficiencies; a simpering, mealy-mouthed magnolia type; voluptuous, happy creatures; a dry, pleasant voice; his wet, warm tongue.

The type of narrative of the novel we have considered is certainly related to its compositional structure. This work is distinguished by the use of descriptions of nature and phenomena that occur around the hero, but to a greater extent - it is a narrative through dialogues and explanations. The main task of the author is to tell her invented story without clarifying her point of view, presenting it only through her characters and their experiences. Here in this book, it is done through the life of Jean Louise, more mature and grownup in comparison with the first book "To Kill a Mockingbird", and her father Atticus Finch. (Koksharova, 2011: 87)

This text presents a large number of dialogues of our protagonists with friends, family members and residents of the city of Maycomb. Dialogue, as the main component of literary prose, helps to reveal the main plot, and also gives the heroes one or another trait and point of view. The dialogues in the fictional text are diluted with narrative and explanatory sentences. All this provides the text with dynamics and liveliness.
The text of the novel contains a large amount of slang, as Harper Lee wanted to demonstrate the trend of realism in her book, so she enriched the speech of her characters with slang expressions typical of those times in the South of America. Among the most common examples are ain't, yonder, wanta, looka and yessum. The work also uses swear words such as hell, damn, nigger. From all this, it can be concluded that the novel mostly illustrates colloquial speech in dialogues, neutral in explanations and narration, with a small amount of professional vocabulary related to the court - courtroom, verdict, plead guilty, felony and jury.

This is one of the fundamental features of this genre of literature - neutral and formal vocabulary is combined with a conversational style, which is expressed both in dialogue and in monologue. (Sachkova, 2012: 61)

\section{Conclusion}

In this article, we examined the definitions of text and style given by many scientists as well as the lexical and stylistic features based on the material of Harper Lee's work "Go, Set a Watchman", which belongs to a group of fictional stories with a demonstration of realistic events.

After the deep analysis of the novel "Go, Set a Watchman" written by an outstanding author Harper Lee, we could make the following summary: the author mostly used such means of expression as epithets and metaphors which benefitted the creation of vivid visual imagery not only of how the characters looked but also how they behaved and reacted to certain events. Therefore, we could sum up that the high use of lexical stylistic techniques can be noted as a style-forming principle. Additionally, the text is replete with dialogues and slang. We could demonstrate these phenomena with the help of multiple examples.

Having analyzed the role of lexical and stylistic techniques and peculiarities in Harper Lee's novel "Go, Set a Watchman", it seems apparent that the linguistic expressive means are helping the author to convey her point of view and to form her individual style.

Modern stylistics covers extensively many questions concerning stylistic devices; however, the studies in this field can proceed. In our opinion, the comparative research of "Go, Set a Watchman" with another Harper Lee's work "To Kill a Mockingbird" can be done to identify the similarities and differences of the lexico-stylistic means used by the same author in two different works. Such kind of research might have a high practical value for linguists. 


\section{Литература}

Бабенко Л.Г. Лингвистический анализ художественного текста. Теория и практика: учебник, практикум для студ. вузов, обуч. по спец. «Филология» / Л.Г. Бабенко, Ю.В. Казарин. - 3-е изд., испр. - М.: «Флинта»: Наука, 2005. - 495 с

Виноградов В.В. Избранные труды: О языке художественной прозы / В.В. Виноградов. - М.: Наука, 1980. - 360 с. Гальперин А.И. Стилистика английского языка / А.И. Гальперин. - М.: Высшая школа, 1981. - 295 с.

Гегель Г.В. Ф. Эстетика. В 4 т. Т. 1. / Г.В. Ф. Гегель. - М.: Искусство, 1968. - 312с

Есин А.Б. Принципы и приемы анализа литературного произведения: учеб. пособие / А.Б Есин. - М.: «Флинта»: Наука, 2000. $-248 \mathrm{c}$.

Жеребило Т.В. Словарь лингвистических терминов / Т.В Жеребило. - 5-е изд., испр. и дополн. - Назрань: Пилигрим, 2010. $-488 \mathrm{c}$.

Кокшарова Н.Ф. Лекции по стилистике (английский язык): учебное пособие/ Н.Ф. Кокшарова; Томский политехнический университет. - Томск: Изд-во Томского политехнического университета, 2011 - 104 с.

Лотман Ю. М. Анализ поэтического текста: Структура стиха: Пособие для студентов / Ю. М. Лотман. - Л.: Просвещение, 1972. $-271 \mathrm{c}$.

Щерба Л.В. Избранные работы по русскому языку / Л.В. Щерба. - М.: Учпедгиз, 1957. - 188 с. $305 \mathrm{p}$.

Carter R., Simpson P. (1989) Language, Discourse and Literature An Introductory Reader in Discourse Stylistics, Routledge,

Haggerty A. (2010) Harper Lee: To kill a mockingbird / by Andrew Haggerty. p. cm. — (Writers and their works), 2010 by Marshall Cavendish Corporation, 127

Lee Harper, Go Set a Watchman, New York, NY : Harper, An Imprint of HarperCollinsPublishers, [2015] 190

McGee S.J. (2002) Analyzing literature: A guide for students. San Francisco, CA: Pearson. Slater, T. \& McCrocklin, S.

Sachkova E.V. Lectures on English Stylistics: Учебное пособие. - М.: МИИТ, 2012. - 94 c.

Simpson P. Stylistics: A resource book for students. Routledge English Language Introductions Series, 2004, 262

Toolan M. (2013) Language in Literature An Introduction to Stylistics. Routledge, 264 p.

\section{References}

Babenko L.G. (2005) Lingvisticheskij analiz hudozhestvennogo teksta. Teorija i praktika: uchebnik, praktikum dlja stud. vuzov, obuch. po spec.«Filologija» [Linguistic analysis of a literary text. Theory and practice: textbook, practical course for students. universities, training. in the special "Philology"]. «Flinta»: Nauka, 495 p. (in Russian)

Carter R., Simpson P. (1989) Language, Discourse and Literature An Introductory Reader in Discourse Stylistics, Routledge, 305 p. (in English)

Esin A.B. (2000) Principy i priemy analiza literaturnogo proizvedenija: ucheb. posobie [Principles and methods of analysis of a literary work: textbook. manual]. "Flinta": Nauka, 248 p. (in Russian)

Gegel G.V. (1968) Estetika [Aestetics]. Iskusstvo, 312 p. (in Russian) English)

Haggerty A. (2010) Harper Lee: To kill a mockingbird (Writers and their works), Marshall Cavendish Corporation, 127 p. (in

Halperin A.I. (1981) Stilistika anglijskogo jazyka [Stylistics of the English language]. Vysshaja shkola, 295 p. (in Russian)

Koksharova N.F. (2011) Lekcii po stilistike (anglijskij jazyk): uchebnoe posobie [Lectures on Stylistics (English): textbook]. Tomsk: Publishing house of the Tomsk Polytechnic University, 104 p. (in English)

Lee H. (2015) Go Set a Watchman, New York, NY: Harper, An Imprint of HarperCollinsPublishers, 190 p. (in English)

Lotman Yu.M. (1972) Analiz pojeticheskogo teksta: Struktura stiha [Analysis of the poetic text: The structure of the verse]. Prosveshhenie, 271 p. (in Russian)

McGee, S.J. (2002) Analyzing literature: A guide for students, San Francisco, CA: Pearson. Slater, T. \& McCrocklin, S. (in English)

Sachkova E.V. (2012) Lectures on English Stylistics: A textbook. M.: MIIT, 94 p. (in English)

Shcherba L.V. (1957) Izbrannye raboty po russkomu jazyku [Selected works on the Russian language]. Uchpedgiz, 188 p. (in Russian) lish)

Simpson P. (2004) Stylistics: A resource book for students, Routledge English Language Introductions Series, 262 p. (in Eng-

Toolan M. (2013) Language in Literature An Introduction to Stylistics. Routledge, 264 p. (in English)

Vinogradov V.V. (1980) Izbrannye trudy: O jazyke hudozhestvennoj prozy [Selected works: On the language of artistic prose]. Nauka, 360 p. (in Russian)

Zherebilo T.V. (2010) Slovar' lingvisticheskih terminov [Dictionary of linguistic terms]. Nazran: Pilgrim, 488 p. (in Russian) 